\title{
Art in the Round: Tradition and Creativity in Early Anglo-Saxon Coinage
}

\author{
Anna Gannon
}

We take it for granted that coins bear images, but we rarely stop to think what an intimate connection actually exists between money and art: it is the design hammered into a blob of metal that turns it into a coin. This is not just pure embellishment. Reflecting on the intellectual leap of imagination achieved in the transition from weighing bullion to trusting coins, it is the iconography that acts as guarantor of fair play and that expresses authority, as is apparent from the earliest coins known. The electrum coins from Lydia, dated to the 7 th century B.C. and minted to very precise weight standards, are powerfully characterized by the protome of a roaring lion, a symbol of the issuing authority. The relationship between money and art is therefore a pivotal one to examine in a volume that explores the roles that money and coinage play in society.

Through the discussion of a number of case-studies, the aim of this chapter is to consider the development of early Anglo-Saxon coinage in the crucial period between the 7 th and 8 th centuries by focusing on the exploration of iconographic choices as artistic responses to specific political and commercial needs within a particular historical, cultural, and social context. In the light of the tumultuous changes of the period in question and the tension between the weight of tradition on one hand, versus the drive towards innovation, creativity, and experimentation on the other, it will offer an overview and commentary concentrating in particular on what shaped the all-important visual elements which were drawn on as sources and signifiers of power, including inscriptions. In an age of ambition and complexity, with a richly diverse visual vocabulary to be drawn on, such a creative response makes "art in the round" an apt label for Anglo-Saxon coins.

The first question we may want to address is whether we are at all justified in exploring these coins through the lens of art, as opposed to regarding them as interesting archaeological/antiquarian artefacts. Much depends on our definition of art - which, for the purpose of this work, will be concerned on the one hand with creative responses and the translation of abstract concepts in the coins, and on the other with their intellectual significance. This chapter will explore the ways in which the Anglo-Saxons rose to the challenge 
of establishing their own independent coinage, as well as the ways in which conceptual drives and resonances directed their iconographic choices. It will become apparent that, although simply reproducing some passable imitations could have been an option, the true merit of Anglo-Saxon coin-makers is to be found in their active response to the challenge of having to fit in with established models while making sure that their creations remained meaningful in their own culture. They did so in a manner that was visually interesting, pleasing, and intellectually stimulating.

It must be conceded that people unfamiliar with the period may find their conventional notions of aesthetics uncomfortably challenged when beholding early coinage. The richly imaginative and creative art of Anglo-Saxon England requires equal testing and stretching of traditional models of aesthetics. The apparent clumsiness of execution of early coins commonly engenders amused curiosity, if not bafflement, especially when they are compared to Greek, Roman, or later medieval specimens, which more readily match classically trained visual sensibilities. In truth, if beauty is in the eye of the beholder, it must be admitted that very often considerable effort is necessary in order to begin to perceive their "iconography", let alone "beauty". However, as shall be argued, there is far more than looks to the early coins, and indeed more than aesthetic concerns when considering them.

Intellectually, our appreciation of the visual culture that developed in Britain and Ireland has advanced and matured considerably in recent times thanks to a number of important scholarly contributions, ${ }^{1}$ so that rather than a stagnant "Dark Ages", the early Middle Ages are now widely perceived as interesting times of change and development. The art of the period has come to be appreciated as a subtle, multi-layered, and learned response to an array of stimuli springing from the political and cultural complexities of the times. The wealth, breadth, and sophistication of contemporary visual vocabularies have come to be recognized and the artists appreciated as witnesses to connections and relations who often helpfully filled the gaps left by the paucity of written evidence. Thanks to this awareness of what can fruitfully be gleaned from visual sources, early medieval coinage is also being investigated in exciting new ways, moving beyond purely numismatic preoccupations with lists and classifications to explore wider multidisciplinary questions encompassing the context of coin production, the ideologies behind it, and the balance between

1 Among many: Henderson, Vision and Image in Early Christian England; Moss, Making and Meaning in Insular Art; Karkov, The Art of Anglo-Saxon England; Webster, Anglo-Saxon Art; and Boulton, Hawkes, and Herman, The Art, Literature and Material Culture of the Medieval World. 
what needed signifying and how meaning could be constructed. Scholars are now interrogating coin iconography more attentively as an expressive symbolic language rich in meaning, and as a window into the socio-economic context and political necessities into which coined money fit.

\section{The Inception of Anglo-Saxon Coinage: New and Old Status Symbols}

It is a well-established fact that for the Anglo-Saxons - who were wellacquainted with, and used and admired fine foreign coins - the decision to mint their own currency at the turn of the 6th to 7 th century meant a reengagement with an activity that had been abandoned for well over a century and a half on British shores. The early coins were of gold, like then-current continental issues, and their production was initially quite localized and restricted, but there is evidence of quite substantial use of coins from the end of the 7 th century. ${ }^{2}$ The period in question was one of major political, religious, and cultural transformations, of which the inception of coinage was but one facet. The decision to mint coins can be understood as a political choice with evident economic benefits.

Particularly in these early stages, with commercial credibility of paramount importance for the fledgling currency to be fully viable, not only were conformity of weight and fineness of metal essential, but design choices needed to conform to other "proper coins". ${ }^{3}$ Hence the iconography on Anglo-Saxon coinage had to rely strongly on the familiar visual pattern set by many foreign coins, themselves re-elaborations of Roman prototypes, displaying a bust on the obverse and a cross on the reverse. Several also retained more or less garbled lettering representing inscriptions, another familiar feature evidently considered necessary for a respectable coin: for illiterate or semiliterate audiences, even pseudo-script acted as an awe-inspiring bearer of authority and bolstered what was transmitted by the designs. Yet, as we shall see, even within such strictures, "imitation" engendered a vivacious intellectual creativity. ${ }^{4}$

Of course, the reality behind the adoption of coinage was far more complex and nuanced than the succinct narrative above appears to suggest. It is worth reflecting on how we tend to assume that the decision to do so was an

2 For a more detailed discussion see Gannon, British Museum Anglo-Saxon Coins I (hereafter SCBI 63), pp. 84-89, and bibliographical references.

3 Gannon, "Imitation is the sincerest form of flattery", pp. 194-95.

4 Gannon, "Imitation", p. 206. 
obviously progressive move on the part of a ruler or a magnate wanting to establish his credentials and proclaim his power in step with the times - and to control and profit from local economy and commerce. However, we should perhaps entertain the notion that it was more likely a leap of faith. When we consider coinage versus more traditional and established signifiers of power and status among Germanic people, such as polychromatic jewellery, we must register a fundamental difference - and therefore a potential problem.

The rich assemblage in Mound 1 at Sutton Hoo (c.620s) $)^{5}$ in East Anglia is a case in point. The regalia consist of a large number of artefacts of exquisite craftsmanship, with finely executed details repaying careful viewing on account of their intricacy and variety of design: the appeal was of an aesthetic of variety. Aside from their magnificent glittering appearance (which could be appreciated, albeit dimly, at a distance), such details could only be perceived accurately and appreciated fully when one was admitted to stand in close proximity to the king himself. Their iconography and craftsmanship were meant to engender admiration and awe in the beholder and perhaps lead to discussion with the king, but in fact this traditional art was essential in the orchestration of highly charged encounters and for defining power structures. Such close and personal interactions were part of the bonding between the leader and his warriors: the importance of status-marking artefacts in Anglo-Saxon warrior society is testified to by the custom of the gifting of precious objects. ${ }^{6}$ The societal importance of beautifully crafted artefacts is also demonstrated by the special position of goldsmiths in the hierarchy of Anglo-Saxon society, ${ }^{7}$ precisely because of their role as royal "image makers".

Coins struck from the same dies, on the other hand, are unsurprisingly pretty much identical, their iconography repetitive. ${ }^{8}$ Their small size still demands close scrutiny of the design, but does not require proximity to the king issuing them or much by way of explanation: their iconography/epigraphy should be self-evident in proclaiming his message of power. Coins are meant for dissemination: they are centrifugal in their message, as opposite to centripetal

5 For the latest discussion of the dating of Mound 1 depositions in relation to the coins, see Archibald, "Numismatics and the chronological model", p. 502; and Archibald, "The Wilton Cross coin pendant", pp. 64-69.

6 Famously, one of the king's appellations in Beowulf (line 1102) is béag-gyfa, the ring-giver.

7 In the early 7 th century goldsmiths were assigned a high wergild, as encoded in the laws of King Æthelberht of Kent: Attenborough, The Laws of the Earliest English Kings, p. 4, item 7.

8 Discussing the subtle differences in the zoomorphic filigree infill panels on the Sutton Hoo shoulder clasps, Noël Adams makes the point that these were deliberate and to do with the belief that perfect matches were ill-omened (Adams, "Rethinking the Sutton Hoo shoulder clasps and armour", p. 87). 
in their lure, in the way that precious objects were meant to be scrutinized and deciphered at close quarters. What we now consider highly advantageous characteristics of a coinage (i.e., standardized production, wide dissemination, inbuilt and clear propaganda) may have actually proven problematic in the cultural milieu of the time. We may hypothesize that neither king nor goldsmith, as official "image makers", took to the new vogue for coins, conceiving them to be but sterile and repetitive objects, offering little scope for virtuosity or pageant - and perhaps especially unhelpful for the engendering of meaningful encounters and social bonding. ${ }^{9}$

The fact that the purse at Sutton Hoo contained 37 Merovingian tremisses, all of different types, has been much discussed..$^{10}$ Whether such variety in the assemblage was intentional or not, the collection was almost certainly exploratory and suggestive of a certain level of interest in these coins. But ultimately it also tells of their inexorable rejection, confined to tinkle in an exquisite and totally traditional bejewelled purse, itself rich in iconography and opportunities for ekphrasis.

To our current state of knowledge, in spite of its wealth and prestige and array of connections, East Anglia appears to have bypassed the "early gold" stage entirely in the minting of its own coinage;"11 there seem to be no local issues until the "pale gold" phase $\left(c .65^{\circ}-675\right){ }^{12}$ Whether this apparent reluctance might be understood as a political expression of resistance to continental Christianity, as argued by Martin Carver, ${ }^{13}$ a preference for more traditional status symbols, or procrastination because of dissatisfaction with the Merovingian prototypes available is open to discussion. Unquestionably though, when the minting of pale-gold coins began in earnest in the region towards the mid65os, it took inspiration from new models altogether, eschewing Merovingian coinage and opting instead for impressive imperial Roman coins as their prototypes.

9 Andrew Woods (personal communication) suggests, however, that there may have been a "performative" aspect to the coinage, with small amounts struck, perhaps on important occasions and in the presence of the king, thus making the minting itself meaningful and the coins special on account of their association to the ceremonial event.

10 Stahl, "The nature of the Sutton Hoo coin parcel", p. 11; G. Williams, "The circulation and function of coinage in conversion-period England", pp. 177-79.

11 However, significant numbers of gold coins have been found at both Rendlesham and Coddenham.

12 SCBI 63, fig. 2, 92-95.

13 Carver, Sutton Hoo, a publication of the fieldwork of 1983-1992. 


\section{Early Interactions with Coins}

It is interesting to consider how many Roman or imported coins (and indeed even early Anglo-Saxon coins and pseudo-coins) were initially transformed into ornaments by the Anglo-Saxons and simply pierced, displayed by means of suspension loops, or mounted in spectacular garnet settings. ${ }^{14}$ Evidence from early Anglo-Saxon cemetery finds testifies that even when worn, Roman coins were highly sought after and often reused as pendants or sewn to clothes. ${ }^{15}$ Such reuse is generally explained as opportunistic "recycling", or as talismanic, ${ }^{16}$ while in the case of impressive pieces, such as the early- 7 th-century Sarre necklace, ${ }^{17}$ which included four gold solidi as pendants, the coins are seen as conspicuous displays of power, connections, accumulated wealth, and aspirations of Romanitas. ${ }^{18}$ However, these modifications and adaptations are to be understood in the context of Anglo-Saxon visual tradition, artistic creativity, and construction of meaning. ${ }^{19}$ By wearing them so prominently, the AngloSaxons would have greatly increased the coins' visual impact. Having transformed them into traditional personal adornments, thereby making it possible for these objects to fit into a long-established culture of display, they would have also facilitated the translation and adjustment of their original symbolic meanings as "coins" into the traditional language of beautifully crafted artefacts as signifiers of power and status so that the meaning of these new exotic things could be better understood and shared by all. It is important to highlight the role of women as wearer of coin jewellery in brokering such change. ${ }^{20}$

The Wilton Cross coin pendant (dating to the second half of the 7 th century), as is well-known, displays the reverse of a Byzantine solidus featuring a cross

\footnotetext{
14 Abdy and Williams, "A catalogue of hoards and single finds from the British Isles", pp. 2229 and $58-59$.

15 SCBI 63, p. 85 .

16 Meaney, Anglo-Saxon Amulets and Curing Stones, pp. 220-21.

17 British Museum 1860, 1024.1. BM numbers designate accession numbers of objects in the British Museum. These can be used to identify specific items via the museum's online catalogue.

18 Gannon, "Money, power and women", p. 214.

19 The custom of wearing coin jewellery is very long-lived, going back to Greek and Roman times. Once reserved for the ruling elites, its use became more widespread down the social scale. From the gth century onwards the fashion in Anglo-Saxon England was for coin brooches (Williams, "Coin-brooches of Edward the Confessor and William I"), their reverses with crosses (often gilded) as their display side, presumably for devotional purposes.

20 Gannon, "Money, power and women", pp. 213-17.
} 
displayed within a cross-shaped garnet setting. ${ }^{21}$ However, as Marion Archibald's careful analysis has demonstrated, the solidus had previously been mounted in a beaded collar with a loop and used as a coin pendant showing the imperial busts, then later modified and set in the pendant, this time privileging its reverse. ${ }^{22}$ The complex biography of the solidus is remarkable, as is the fact that essentially the original coin jewel as first conceived lives on in the new setting. We can only postulate that the new Christian meaning was layered on top of whatever noteworthy significance the coin had originally acquired as a pendant.

The transformations of coins from functional tokens to traditional ornaments can thus be recognized as a form of clinging on to old customs - a powerful force, as argued earlier in the context of the assemblage at Sutton Hoo. However, even the making of ornaments out of coins is a significant early stage, a positive interaction with coinage which paved the way to the next logical step: their minting in Anglo-Saxon England. It is valuable to recognize such first dealing with coins as one of two interlocking levels, both engendering some form of transformation. ${ }^{23}$ If the first stage may be defined as conservative and relating to foreign coins merely as prestigious objects which lent themselves to transformation into precious artefacts, the second stage witnesses a far more dynamic and critical engagement with the prototypes, and in particular their iconography, leading consequently to the taking over and transformation of designs to suit local tastes and interests. At both levels of interaction new, relevant meanings would have been created and ascribed to the coins.

\section{Models: Inspirations and Ambition}

From the geographical extent of the early numismatic finds recorded in the British Isles, it is clear that Anglo-Saxon moneyers, the people in charge of choosing the designs of the coins and who were also guarantors of the quality of their metal, had access to quite a large selection of possible models and prototypes: in addition to ancient British coins, known finds include imperial

21 British Museum 1859, 0512.1 (see figure 1.3, p. 14). The lightweight solidus was struck in the name of the emperor Heraclius (610-641) and his son and co-emperor Heraclius Constantine $(613-641)$.

22 Archibald, "The Wilton Cross ", pp. 58-6o and figures 1.(5) and 1.(6).

23 Although specifically dealing with Paleolithic times, Steven L. Kuhn explores the transitions in the ways early humans employed signalling media and discusses personal ornaments as vehicles for social signalling, eventually becoming abstracted and independent from the individual. Kuhn, "Signaling theory and technologies of communication in the Paleolithic". 
coins from Rome and Byzantium, pseudo-imperial Frankish, Visigothic, Burgundian, Ostrogothic, Lombard, and Alemannic coinage, various Merovingian issues, and Frisian and even some Sasanian coins. ${ }^{24}$ The vigour of the AngloSaxon response to the challenge to produce their own currency is demonstrated by the earliest of the Anglo-Saxon coins, the gold shillings or tremisses. We know a number of these from the large Crondall hoard (dated to the 640s) and other approximately contemporary finds from further afield, such as the group from York. ${ }^{25}$ These early stages of minting present us with a snapshot of the motifs available and the range of responses they engendered.

At the early stage of coinage, three main iconographic strands can be discerned as influential, particularly with regard to the treatment of the busts: one focuses on contemporary, mainly Merovingian prototypes; another makes reference to some distinctive traits of Romano-British coinage; while the third and most prestigious is derived from classical sources, predominantly historic Roman coins. It is remarkable how, in spite of the iconographic diversity among these coin types, they all coexisted and conformed in fineness.

Contemporary continental coins, mainly Merovingian, furnished some useful models in the tentative early a stage of Anglo-Saxon coinage; however, in general their influence was temporary and not universal, as already argued for East Anglia. This may have been because the practical concern regarding the need to conform to well-established numismatic models was a relatively short-lived factor, and probably not the main consideration to play a part when deciding on a suitable iconography. We can speculate that far more determining factors would have been the symbolic value and prestige attached to the prototype.

Gold Benutigoii coins provide a good example of Merovingian-inspired iconography: they feature neat profile busts with small heads of sharp, linear features, pellet-like eyes, and hair swept back above a diadem. ${ }^{26} \mathrm{~A}$ circle separates the heads from the inscriptions, which are either of runic or Roman lettering. ${ }^{27}$ Only a small handful of coins of this type are known: aside from one pair, all are from very different dies and vary widely in size and details, yet the design is distinctive enough to convey a sense of unity, regardless of obvious discrepancies. Presumably this was also the perception in Anglo-Saxon times; yet, it is

\footnotetext{
24 Abdy and Williams, "A catalogue", pp. 29-58; G. Williams, "Circulation and function".

25 SCBI 63, pp. 85-92.

26 SCBI 63, pp. 89-9o, nos. 7-9. They would influence the early silver Bx Series: ibid., p. 101, nos. $67-68$.

27 Also, on the reverses, small equal-armed crosses are surrounded by radiating, rather untidy lettering.
} 
instructive to consider how the three Benutigoii specimens now in the British Museum were originally housed in separate cabinets: because of the different scripts used, only one was believed to be Anglo-Saxon, and the other two were considered continental. This serves as a cautionary tale: our approach to coins is biased by our ideas and priorities. From our literate vantage point, inscriptions are considered to be the main bearers of meaning - however, for a largely illiterate society like that of early Anglo-Saxon England, script may have been an awe-inspiring and mysterious bearer of authority, but arguably the look of the "bust" and other images mattered more for identification.

An important contribution not often brought to bear on numismatic studies of the period, because it has not as yet been fully assessed vis-à-vis AngloSaxon coinage, is the debt to ancient British coins, which, then as now, would have been relatively common finds. While questions regarding continuity, change, and acculturation between the post-Roman British and Anglo-Saxons are well beyond the scope of this chapter, this cultural layer is fundamental. ${ }^{28}$ The role that the post-Roman British population played - by mediating the Anglo-Saxon perception of continuity with the Roman past and through the visible examples of their former interactions, including the eclectic images on their old coinage - is well worth further investigation. Certain points of contact, continuity, and overlap are clearly discernible between Anglo-Saxon and "Celtic" art. These would culminate in that "fusion" known as Insular art, as powerfully highlighted in a 2015-2016 exhibition at the British Museum and National Museum of Scotland. ${ }^{29}$ It is significant that some of them can be observed in connection with coinage as well, with pre-Roman British coins furnishing inspiration to Anglo-Saxon counterparts from their inception until the early 8th century. ${ }^{30}$ Among several examples, one may mention the shared emphasis on hair and the common interest in the rendering of hair and diadems as pattern: as points of comparison, the so-called "Ladder Head" coins of Commios (c.50-25 B.C.) and the upright, stiff hair seen on several of the AngloSaxon coins, including the international Porcupine motif. ${ }^{31}$ Frontal images of

28 Esmonde Cleary, The Ending of Roman Britain, p. 167.

29 Farley and Fraser Hunter, Celts, pp. 176-82; Webster, Anglo-Saxon Art, pp. 99-108.

30 Gannon, "Insular numismatics: the relationship between ancient British and early AngloSaxon coins".

31 On Commios: Cottam, de Jersey, Rudd, and Sills, Ancient British Coins, pp. 1034-40; see also 1564. For the Anglo-Saxon coins, see, for example: "Bust LOND" (no. 71) in Metcalf, Thrymsas and Sceattas in the Ashmolean Museum, Oxford; and Gannon, The Iconography of Early Anglo-Saxon Coinage, pp. 36-37 and figs. 2.18-2.20 and 2.37a. The characteristic "quills" of so-called Porcupines, i.e., Series E (ibid., pp. 176-81; SCBI 63, pp. 110-12) are also derived from such rendering of the hair. 
Romano-British gods, such as Belenus, Cernunos, and Medusa, ${ }^{32}$ bolster the identification of "facing heads" on Anglo-Saxon coins as sacred images; ${ }^{33}$ but most importantly, there are some telling points of contacts in the treatment of inscriptions.

As Jonathan Williams has discussed in the context of the uptake of Latin on British coin inscriptions, the Roman-inspired staters of Tincomarus (c.25 B.C.A.D. 10), featuring a finely modelled galloping horseman in classical style on their reverse, have on their obverse the inscription сом $\cdot \mathrm{F}$. (son of Commius) in perfectly correct Latin and canonical epigraphic style, displayed within a tablet or cartouche in a way that was innovative and had no Roman numismatic precedent. ${ }^{34}$ However, this pattern would prove quite influential for AngloSaxon coinage: among the pre-primary Pada series (c.675-68o), for instance, the runic name is always displayed horizontally within a rectangular standard, at the side of it (Figures 12.1a and b), or in a round frame. ${ }^{35}$

The more complex TTOII-inscribed standard, ${ }^{36}$ a long-lived design derived from the Pada coinage, descended through the substantive silver Series A, C, and $\mathrm{R}\left(c .68 \mathrm{O}-c .75^{\circ}\right)$ (Figure 12.2) and, with various modifications, is also behind other major series and types, such as the Porcupines of Series E. ${ }^{37}$

Together with the more classical fashion of numismatic inscriptions disposed along the inside of the rim of a coin, the tradition of horizontally displayed inscriptions would long endure on Anglo-Saxon coinage, as testified to by the many examples produced by King Offa (both with his name and those of his moneyers, even displayed on pelleted standards), ${ }^{38}$ and continuing until

32 See for instance, Cottam, de Jersey, Rudd, and Sills, Ancient British Coins, 2912, 1109 and 1076 .

33 Gannon, "Coins, images and tales from the Holy Land" and "Firmly I believe and truly".

34 J. Williams, "Coin inscriptions and the origins of writing in pre-Roman Britain", pp. 9-16; Cottam, de Jersey, Rudd, and Sills, Ancient British Coins, 1064-67, on type BM 770 (VA 385; Mack 10o). Williams comments on p. 10 that the epigraphy and its setting in a cartouche have counterparts in Roman stamps on bricks, etc.

35 SCBI 63, nos. 31-33. Pada is understood to be the name of the moneyer (ibid., p. 95).

36 The ттог inscriptions are understood to be derived from lettering amalgamating different numismatic models (Gannon, Iconography, p. 172, n. 106), including depictions of inscribed votive altars (e.g., Constantine I), which may have also been known at first hand. Hence, the impact of monumental inscriptions on both British and Anglo-Saxon coins should be considered. Mattingly, Sydenham, et al., The Roman Imperial Coinage, Vol. 7,305 .

37 Gannon, Iconography, pp. 171-76, and SCBI 63, nos. 42-66, 117-37, 306-418, and 627-710.

38 See, for instance, "Heavy coinage of Canterbury (Æthelmod)", Chick, The Coinages of Offa and His Contemporaries, pp. 153-57, Types 229-36. For standards, see "Light coinage of Canterbury (Eoba)", Ibid., pp. 108-12, Types 104-11. 

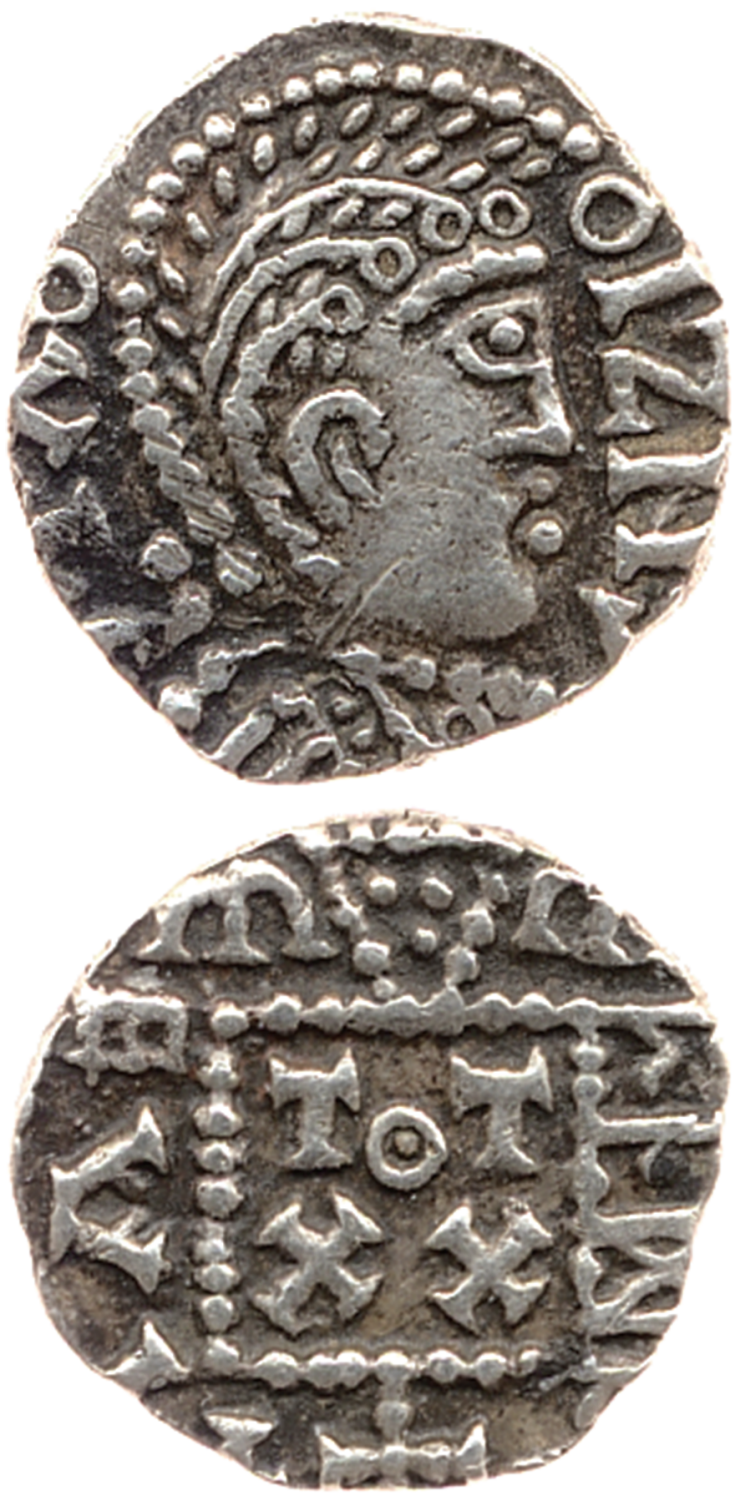

FIGURE 12.1A "Pada", Type PIb. Obv. helmeted bust right. Rev. banner containing тот / Xx, "pada" in runes to right.

SOURCE: FITZWILLIAM MUSEUM, CAMBRIDGE (MEC 8, NO. 15; CM.15662007). 

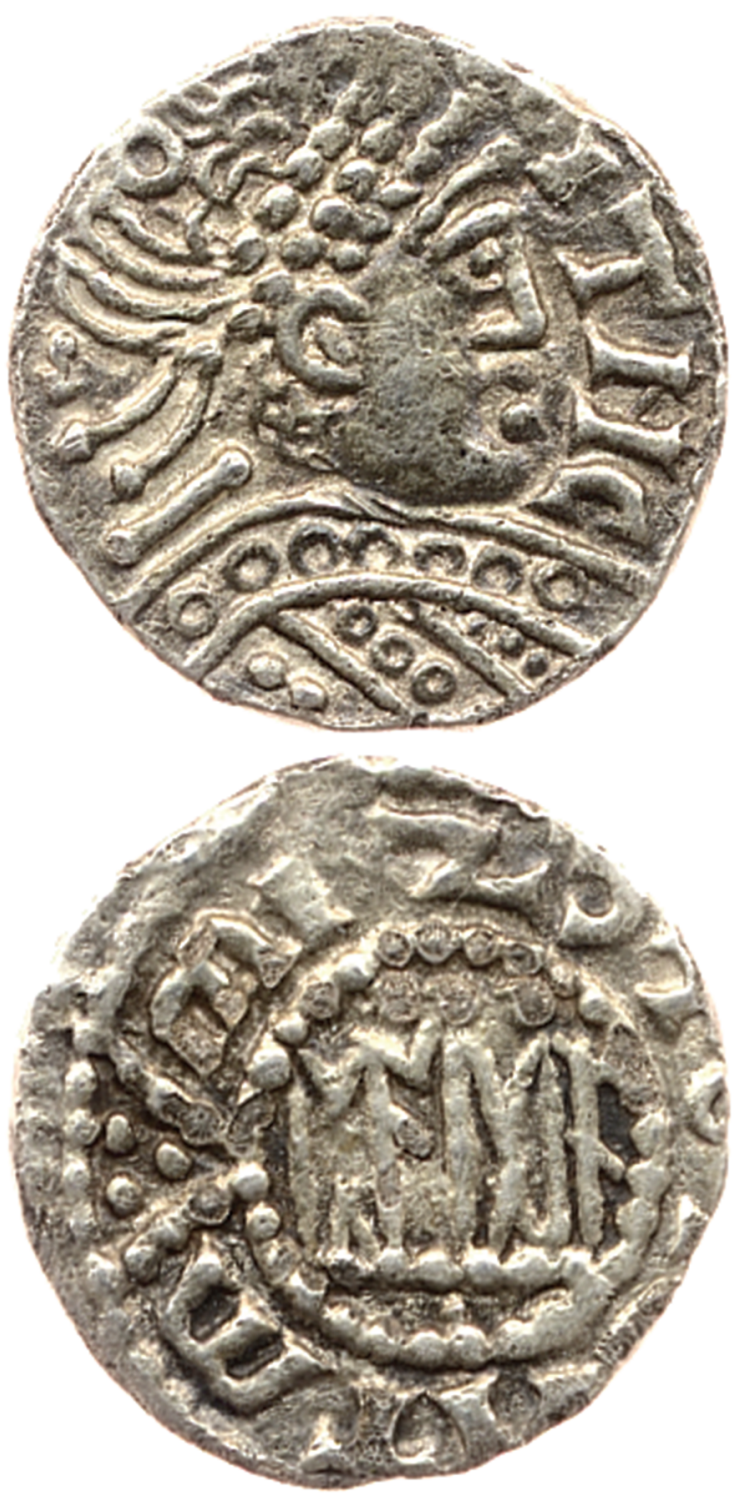

FIGURE 12.1B "Pada", Type PIIa. Obv. diademed bust right. Rev. "pada" in runes in circle. SOURCE: FITZWILLIAM MUSEUM, CAMBRIDGE (MEC 8, NO. 16; CM.1567-2007). 

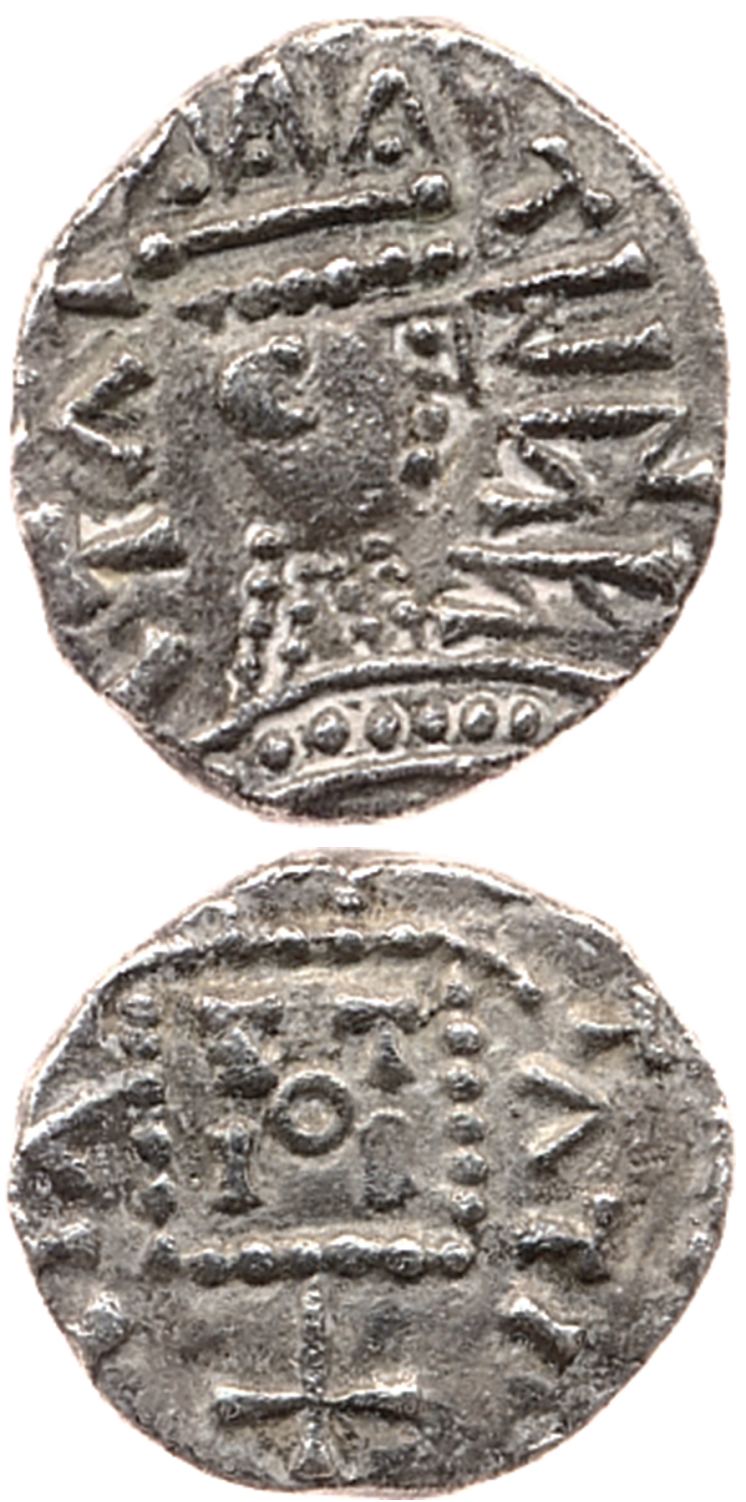

FIGURE 12.2 Series R, Type Rı. Obv. "epa" in runes before radiate bust right. Rev. standard containing T о T/I I, cross below and pseudo-letters to either side SOURCE: FITZWILLIAM MUSEUM, CAMBRIDGE (MEC 8, NO. 78; CM.19142007). 
the late 1oth century with various horizontal types over two or three lines, clearly displaying the names of various moneyers. ${ }^{39}$

Whether in the early stages of Anglo-Saxon coinage these particular choices and the aesthetics they evoked were meant to adumbrate charged political undercurrents, or if they were simply a matter of model availability and convenience, or indeed traditional continuity of craftsmanship, are questions impossible to ascertain. While the influence of British coinage and cultural tradition in filtering Roman appreciation are undeniable, the main source of inspiration and ambition for Anglo-Saxon coin-making was undoubtedly Rome itself. Hence it is to the interaction with Roman heritage in Britain and the influence of Roman coins that the discussion will now turn.

\section{Imagining Rome}

The Anglo-Saxon relationship with the cultures of Rome and the physical remains of the Empire in Britain was as intimate as it was complex. Although the Anglo-Saxons had not themselves been directly under Roman rule, they had had interactions with Rome as a political and economic power, and in some cases a certain amount of first-hand experience would have derived from service in the Roman Army before migrating to Britain. ${ }^{40}$ Once the Anglo-Saxons had settled in Britain, prominent vestiges of mighty Rome and its imperial past were ubiquitous. Although Nicholas Howe talks lyrically of a postcolonial void, of decay, depopulation, and melancholy, and even if by then in various states of disrepair, monuments and remains were definitely impressive, conditioning and stimulating artistic and literary responses and contributing positively to a wilful mental construct of continuity and belonging, as well as to a sense of a tangible Roman past and heritage. ${ }^{41}$ Arguably, the phenomenon of transformation/translation of numismatic prototypes seen in Anglo-Saxon coinage (which engendered cultural overlap, experimentation, and a rhetoric of hybridity) could lend itself to probing through the lens of postcolonial theory. ${ }^{42}$

39 For the 1oth-century coinage, see Archibald and Blunt, British Museum Anglo-Saxon Coins 5 (hereafter SCBI 34). Aside from issues of improved legibility, the horizontal display of inscriptions on "lines" is reminiscent of the enhanced appearance of English legal documents (Webster and Brown, The Transformation of the Roman World, p. 220).

40 As testified to by, for instance, the belt-sets and buckles, as well as their imitations found in Britain: see White, Roman and Celtic Objects from Anglo-Saxon Graves.

41 Howe, "Anglo-Saxon England and the postcolonial void", pp. 28, 41; Howe, Writing the Map of Anglo-Saxon England.

42 This is an approach taken by Karkov, The Art of Anglo-Saxon England. 
However, while certainly useful in suggesting a more nuanced approach when thinking about the embracing of Romanitas, it is important to remember that the relationship between Anglo-Saxon England and Rome was constructed entirely willingly, rather than imposed.

With regard to influential models furnished by imperial Roman coinage, then as now hidden caches and casual losses would have been relatively common, and would have offered enthralling sources of inspiration for multiple generations. The Anglo-Saxons' salvaging and reuse of coins, as already discussed, is evidence of the continuing allure of Rome, and of a burgeoning appreciation and presentation of what they believed Rome to stand for. It could be argued that the use of Roman coins, first as ornaments and then as iconographic models for native coinage, is to be perceived in a symbolic act akin to the deliberate appropriation of Roman spolia as carried out in early Christian basilicas in Rome and post-Conversion Anglo-Saxon buildings, ${ }^{43}$ and embodying an unequivocal appeal to Romanitas in its manifold implications. ${ }^{44}$ Thus, the selection of a particular Roman prototype as a model for an Anglo-Saxon coin would have been a highly charged undertaking, intended to encapsulate within the native coin something of the authority and gravitas of the original and turn it into an embodiment of power.

At first, the Anglo-Saxon renderings transform details to suit native aesthetics - in possible pursuit of "the look of power": hair, as discussed, and headgear, as well as rich texture and pattern-making in the drapery. One of the finest of the early imitations of Roman exemplars is the very striking left-facing Licinivs type in the Crondall hoard (c.640). ${ }^{45}$ It features sensitive modelling of the face in high relief, with strong eyebrows, diadem, and abundant hair convincingly rendered - yet much of the design focuses on pattern-making, particularly so on the richly detailed and textured garments. In a similar manner, pellets are scattered lavishly between and through the peaks of the impressive radiate crown of the mid-7th century Concordia Militum type, ${ }^{46}$ an exaggerated rendering of the curly hair of the Roman originals. The treatment of the helmet on the Crispus/delaiona type is also notable: ${ }^{47}$ some of the Roman coins of Crispus show helmets chased with volutes of vegetation, ${ }^{48}$ but the Anglo-Saxon

43 Eaton, Plundering the Past, p. 128; Howe, Writing the Map, pp. 91-97; and Coates-Stephens, "Epigraphy as spolia".

44 Coz, Rome en Angleterre.

45 Metcalf, Thrymsas and Sceattas, nos. 33-41.

46 SCBI 63, nos. 19-20.

47 SCBI 63, no. 21.

48 E.g., Mattingly, Sydenham, et al., The Roman Imperial Coinage, Vol. 7, p. 281. 
rendering is actually more akin to representations of the hairstyle on the antoniniani of Ulpia Severina $(270-275)^{49}$ and turns the headgear into geometrical patterns of concentric Cs.

The plentiful late 4th-century "Two Emperors" type offers an example of a prestigious design with a very wide appeal: not only do we have an early gold imitation mounted as a pendant, ${ }^{50}$ but the "Two Emperors" counts as the most common type among the pale gold shillings $(c .660-670){ }^{51}$ The design is manipulated to best fit the small size of the coins - hence it focuses on the three heads (the emperors and the "victory") and the shared globe, with the central struts of the throne forming a prominent saltire (Figure 12.3).

Familiarity with the Roman prototype accounts for the return to the original two seated emperors on rare silver pennies struck in the names of King Alfred of Wessex (r. 871-899) and King Ceolwulf II of Mercia (874-879). ${ }^{52}$ The coins were well-represented in the Watlington Hoard (dated to the late 870 s), and have contributed to a reassessment of the history of this period..$^{53}$ The fact that the coins were struck at different mints and over several years proves that there was a political allegiance between the two kings that lasted over a number of years. The subtle manipulation of the Roman prototype so that the kings could be shown sitting facing each other and interacting is thus vindicated. ${ }^{54}$

Another instance of a long and varied use of Roman numismatic imagery is derived from the Constantinian type Urbs Roma. Aside from its famous reproduction, both obverse and reverse, on the $5^{\text {th- }}$ and 6th-century Undley Bracteate, ${ }^{55}$ in the first half of the 8th century the motif of the she-wolf and twins was deployed on silver coins of Series v, albeit in a rather reworked form, with "adult" twins taking up most of the flan, and, as I have argued, with religious connotations (Figure 12.4). ${ }^{56}$

A comparable shift of meaning and iconography, again with grown-up twins but this time attended by two wolves, features on the Franks Casket, ${ }^{57}$ an elaborately carved whalebone box, aptly labelled "self-consciously clever".58

E.g., Mattingly, Sydenham, et al., The Roman Imperial Coinage, Vol. 4. For recent finds of these coins in England see: https://finds.org.uk/database/search/results/show/4o/sort/ created/broadperiod/ROMAN/thumbnail/1/rulerName/Severina.

$5^{\circ} \quad$ Ashmolean Museum 1942, 220. See Gannon, Iconography, fig. 3.7.

$5^{1}$ SCBI 63 , nos. 22-30.

$5^{2}$ See also Karkov, The Ruler Portraits of Anglo-Saxon England, p. 26.

53 The Watlington Hoard (Oxfordshire) was found by a metal detectorist in October 2015.

54 Gannon, Iconography, pp. 84-87.

55 British Museum 1984, 1101.1; see Webster, The Franks Casket, p. 41, fig. 31.

56 Gannon, Iconography, pp. 144-48; Neuman de Vegvar, “The travelling twins", pp. 256-67.

57 BM 1867, o120.1; see: Webster, Franks Casket, p. 40, fig. 29.

$5^{8}$ Wood, "Ripon, Francia and the Franks casket", p. 5. See also below. 

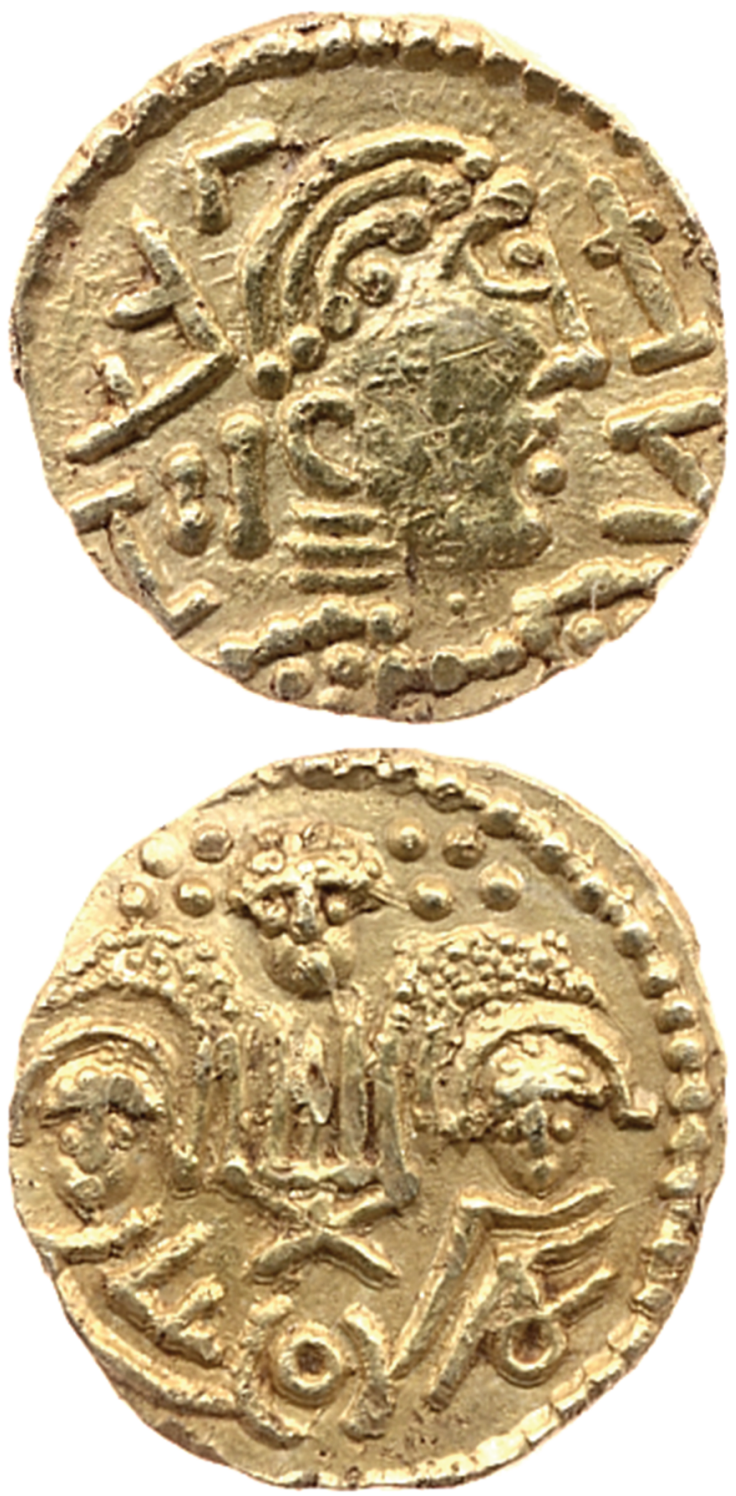

FIGURE 12.3 "Two Emperors" type.

SOURCE: FITZWILLIAM MUSEUM, CAMBRIDGE (MEC 8, NO. 9; CM.15622007). 

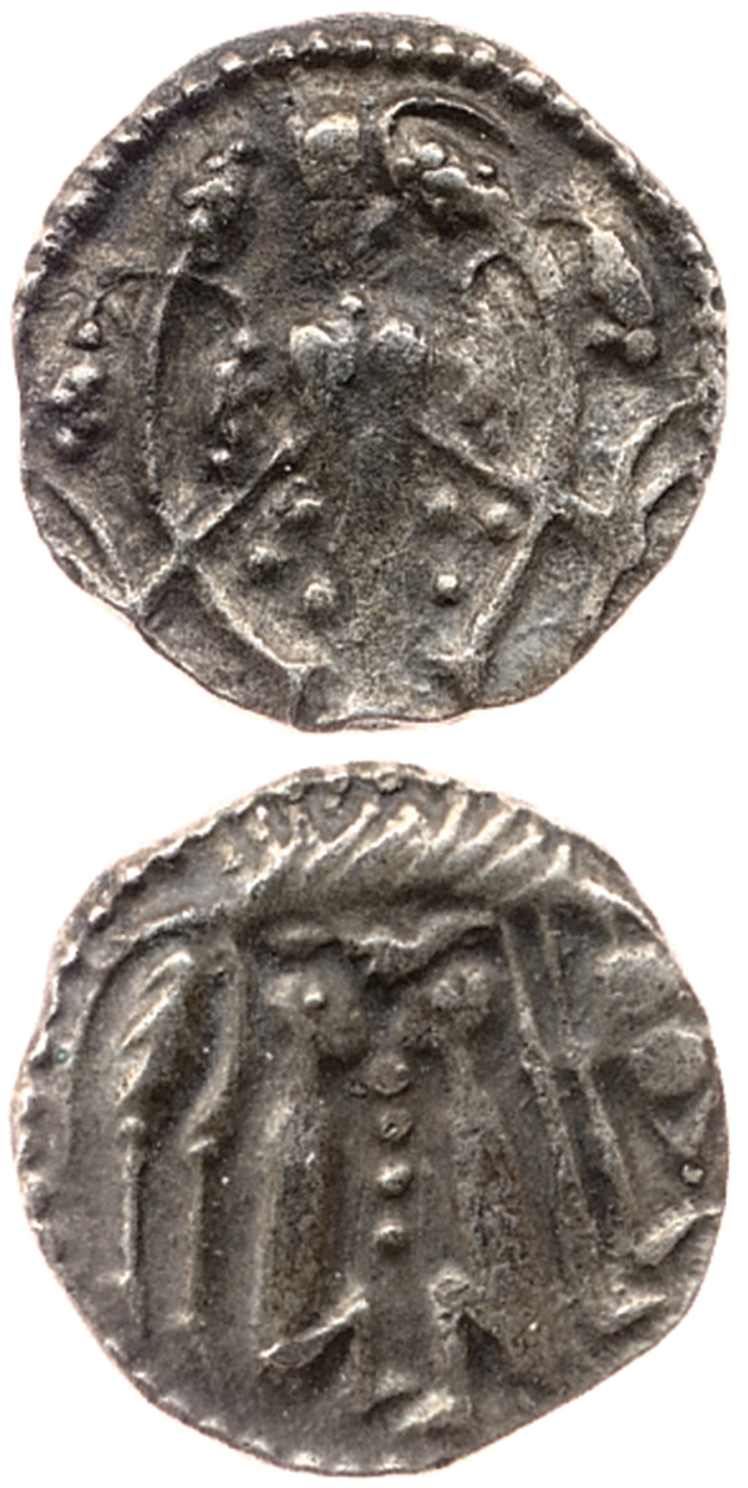

FIGURE 12.4 Series V (Type 7).

SOURCE: FITZWILLIAM MUSEUM, CAMBRIDGE (MEC 8, NO. 619; CM.1977$2007)$. 
In the late 8th-century, the East Anglian moneyer Lul, working for Æthelberht II (d. 794) and then Offa of Mercia (d. 796), returned to a traditional Constantinian model for his take on the she-wolf and twins, a striking and unique reverse which he used for both kings. ${ }^{59}$ We may wonder whether the re-use of the Roman motif (crowned by the word REX) was meant as a charged gesture of defiance on the part of Æthelberht, a pun on the dynastic name Wuffingas, a homage to Rome as Mother Church, or a proud revival of the tradition of using Roman numismatic prototypes in East Anglia. The answer may have been complex and itself multilayered. ${ }^{60}$ Arguably such a major paradigm shift in the deployment of coin iconography - from practical use to intellectual appropriation and transformation - was helped and mediated by the adoption of Christianity and its ingrained practice of seeking layers of significance and moving from literal to spiritual meanings.

\section{The Conversion to Christianity}

As James Campbell strikingly put it, it was through the Conversion that barbarians moved from "eating from a Roman plate to believing themselves Roman".61 Howe has argued that after the Conversion, the relevance of Rome for the Anglo-Saxons morphed from historical to current, Rome having become the location of Mother Church. ${ }^{62}$ They most certainly considered themselves "heirs of Rome", where the imperial and Christian appear to have neatly coincided and overlapped. ${ }^{63}$ The adoption of the new religion, along with its traditions of Latin and literacy and the minting of coinage, were important strategic indicators of assimilation and facilitated claims and corroboration of royal claims to power, both internally and abroad. In addition to a more intellectualized perception of the imperial past, the increasingly direct relationship with Rome itself and the extensive travelling and importation of commodities necessary for the establishment and upholding of the fledgling Anglo-Saxon Church augmented the cultural and visual vocabulary available. All this stimulated far more ambitious undertakings in the arts, including what was then attempted on the coinage, particularly in the silver series of the first half of the 8th century.

\footnotetext{
59 Naismith, Money and Power in Anglo-Saxon England, p. 152.

6o Gannon, "Three coins in a fountain", pp. 294-302, figs. 13.2-13.5.

61 Campbell, "The first Christian kings", p. 67.

62 Howe, Writing the Map, p. 101.

63 Howe, "Anglo-Saxon England", p. 38.
} 
To this period also belongs what is arguably the earliest representation of coins in Anglo-Saxon art. Perhaps unsurprisingly, it is found on the Franks Casket, ${ }^{64}$ a most remarkable object which bears witness to the way in which the Anglo-Saxons engaged with learning by means of metaphors, complex correlations, and ultimately transformation of meaning. In panels framed by bands of riddling runic writing, the casket juxtaposes and invites comparisons between scenes derived from Germanic legends and Christian and historical sources. The right of the front panel portrays the Adoration of the Magi. ${ }^{65}$ The first of the three kings to present an offering to the Infant Christ holds a chalice with three "discs" atop. Traditionally, the present is supposed to be of gold, hence the chalice can be interpreted as brimming over with gold coins. However, in the riddling context of the casket, we are invited to meditate upon the transformation of the earthly treasure of precious coins into hosts, presented in a chalice as sacred Eucharistic offering, the ultimate gift of Salvation, far more precious than any gold coins - a sort of transubstantiation.

Although well-understood as mirroring the intense early 8th-century Zeitgeist, the casket's patronage, its intended recipient(s), and whether it should be understood as belonging in a monastic or secular milieu are questions long debated by scholars. ${ }^{66}$ Its extraordinary interplay of imagery and layering of meaning have parallels in the art of some of the contemporary silver coinage of which the very same questions are also now being asked.

\section{The Silver Coinage}

By the turn of the 8th century, through progressive debasement and for enhanced convenience, Anglo-Saxon England as well as the continent struck coinage in silver: these silver pennies are the so-called sceattas. By this time coinage was utilized quite extensively across wider areas, including East Anglia and the Midlands and, of course, across the North Sea. By far the most widely used types were the socalled Porcupines (Series E). These were very plentiful and important commercially, and distinctive for their almost abstract design which, on account of its plentiful production, needed to be of rapid execution, but had no artistic pretence. ${ }^{67}$

\footnotetext{
64 Webster, "The iconographic programme of the Franks casket"; Webster, Anglo-Saxon Art, pp. 91-97; and Webster, Franks Casket.

65 See illustration in Webster, Franks Casket, p. 35, fig. 22.

66 Karkov, Art of Anglo-Saxon England, p. 147.

67 Gannon, Iconography, pp. 176-81; SCBI 63, pp. 110-12.
} 
Far more engaging visually and intellectually are the many types of sceattas which introduce innovative iconographies. Among them are to be found a remarkable avidity for experimentation and a great wealth of human figures, animals, birds, and vegetation motifs, as well as intricate patterns and crosses and interesting takes on busts. ${ }^{68}$ Their designs were more often than not derived from non-numismatic sources. Some are demonstrably based on Roman gems, presumably local finds, while for others we can only postulate the availability of some quite exotic prototypes. ${ }^{69}$ The appropriation of imagery derived from gems must be viewed in a similar way to the spolia discussed above: these trophies from the past added distinction to the present, albeit with no awareness of their original meaning or context, as demonstrated by the misunderstanding of details in the composition. ${ }^{70}$ As an example, we can compare the treatment of Hercules, a subject found both on coins of Cunobelinus (c.A.D. 8-41) and a unique sceat in the Ashmolean Museum. ${ }^{71}$ While the British coin shows a good awareness of some original classical prototype, with a naked, muscular Hercules holding a club and the Nemean lion's skin, the Anglo-Saxon rendering (from a different model, ${ }^{72}$ with Hercules slaying the Hydra) depicts a slim figure dressed in a long tunic, while the monster and the lion's skin (not understood as such) have dissolved in vegetation motifs. Only the pose of the original, with the raised arm holding a club, remains. What meaning this reworked image was intended to convey remains uncertain: it fits alongside other coins showing figures among vegetation, but stands out among them as elegantly appropriating a Roman "original".73

We witness equally striking innovations across the whole breadth of the artistic output of the time, which has fittingly been called the golden age of Anglo-Saxon art. Intellectually much of the iconography of these particular sceattas is steeped in complex religious imagery and reveals knowledge of and active engagement with the major theological issues and controversies of the

\section{Gannon, Iconography.}

69 Gannon, Iconography, p. 185; see figs. 2.63/2.64 and 4.37a/4.37b for the use of two related Bacchic gems as the obverse/reverse of coins of Series K, Type 42.

70 Gannon, Iconography, p. 93.

71 On Cunobelinus: Hobbs British Iron Age Coins in the British Museum 1884-1885 and see Cottam, de Jersey, Rudd, and Sills, Ancient British Coins, 2864. The Anglo-Saxon coin is no. 361 in Metcalf, Thrymsas and Sceattas, and illustrated in Gannon, Iconography, Fig. 3.18a.

72 An example of a possible iconographic source is the gem illustrated in Gannon, Iconography, Fig. 3.18b.

73 Gannon, Iconography, pp. 94-95. The "vegetation" on these sceattas is often a sinuous fruited plant, presumably a vine. See below for a discussion on the iconography of birds in vines. 
time. ${ }^{74}$ Thus, in addition to more straightforward-seeming symbols such as crosses, ${ }^{75}$ the coins explore far more complex iconography relating (for example) to the growing importance of the cult of the Virgin Mary (Figure 12.5) ${ }^{76}$ or the nature of Christ and His representation in the form of a lamb. ${ }^{77}$

Visually, while many useful comparanda have been lost, enough survive among manuscripts, sculpture, and metalwork to justify the claim that these sceattas not only bear witness to the intellectual refinement of the times, but can be seen to fit in artistically among "related sets of objects within a single standard and context of patronage".78

As already noted, from the early times of production, inscriptions had formed a major part in coins' credibility - yet, notoriously, sceattas carry very few. This is due partly to their small size, but also to the fact that their iconography is far more complex. A few are very competently inscribed in Latin characters and are exceptional models of legibility, but the majority are garbled and tokenistic (Figures 12.6a and b). ${ }^{79}$ The short runic inscriptions (or pseudoinscriptions, as they tend to degenerate) ÆPA/APA/EPA, which are understood to have originally represented the name of a moneyer, appear in front of the busts of Series C and R (see Figure 12.2). ${ }^{80}$

In observing how much the Anglo-Saxons were exposed to texts, labels, and inscribed, speaking objects, Catherine Karkov posits that images and text were perceived as equal in conveying meaning, ${ }^{81}$ while Rory Naismith, commenting specifically on coins, states that letters functioned as a verbal as well as a visual manifestation of authority. ${ }^{82}$ With these observations in mind, we can move a step further in thinking how the combination of script and bust may have been received and understood by their viewers, perhaps even at a performative level. We may postulate that the inscription which endorses the moneyer's name on behalf of the authority represented by the bust actually gives the bust a voice, so that as a result the mandate is perceived to be conveyed not only visually, but

\footnotetext{
74 Ó Carragáin and Thacker, "Wilfrid in Rome".

75 See Gannon, Iconography, pp. 161-65 for composite and hidden crosses as devotional patterns akin to carpet pages in Gospel books.

76 Gannon, “Coins, images and tales", pp. 99-103.

77 Gannon, "Firmly I believe and truly".

78 Plunkett, "The Mercian perspective", p. 210.

79 Particularly fine are $S C B I 63$, pp. $55^{8-59}$. See the discussion regarding the imitation and subsequent degeneration of the original inscription DE LVNDONIA among Series L, "Celtic Cross and Rosettes," and DELVNDONIA/MONITASCORVM/sCorvm types: SCBI 63, pp. 11923 and nos. 524-32, 549, and 558-61. See also Naismith, "Money of the saints", pp. 83-87.

8 o SCBI 63 , nos. $117-37$ and $627-710$.

81 Karkov, Art of Anglo-Saxon England, pp. 135-37.

$82 \quad$ Naismith, Money and Power, p. 79.
} 

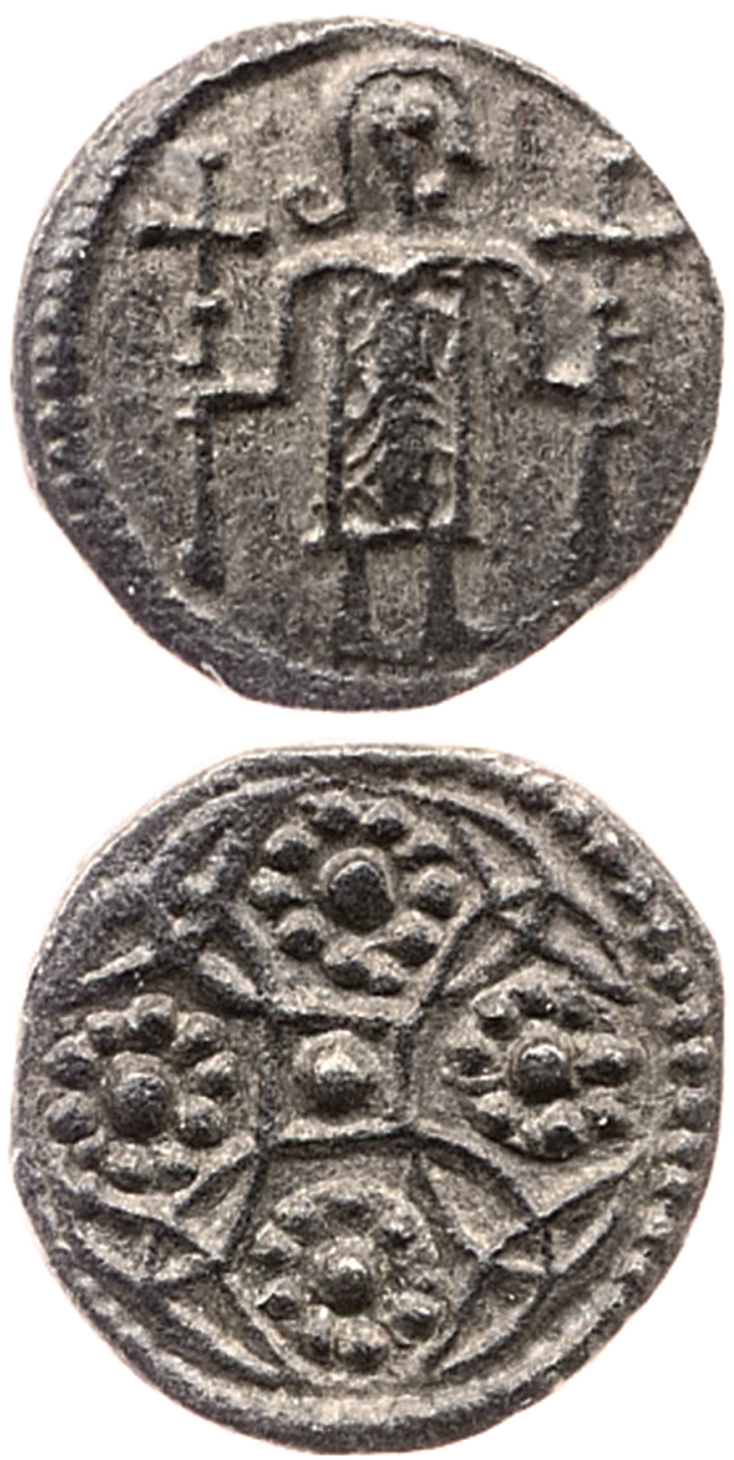

FIGURE 12.5 “Cross and Rosettes", Type 106 variant.

SOURCE: FITZWILLIAM MUSEUM, CAMBRIDGE (MEC 8, NO. 433; CM.1832-2007).

aurally. ${ }^{83}$ Of course, over-familiarity with the combination of bust and inscription and the sheer volume of coins produced would have led to all but cursory

83 I have argued (Gannon, Iconography and the Visual Imagination) that this voicing of the inscription can be compared to the interpretation of the healing "breath" on bracteates (Hauck, "Gott als Arzt", pp. 19-62). 

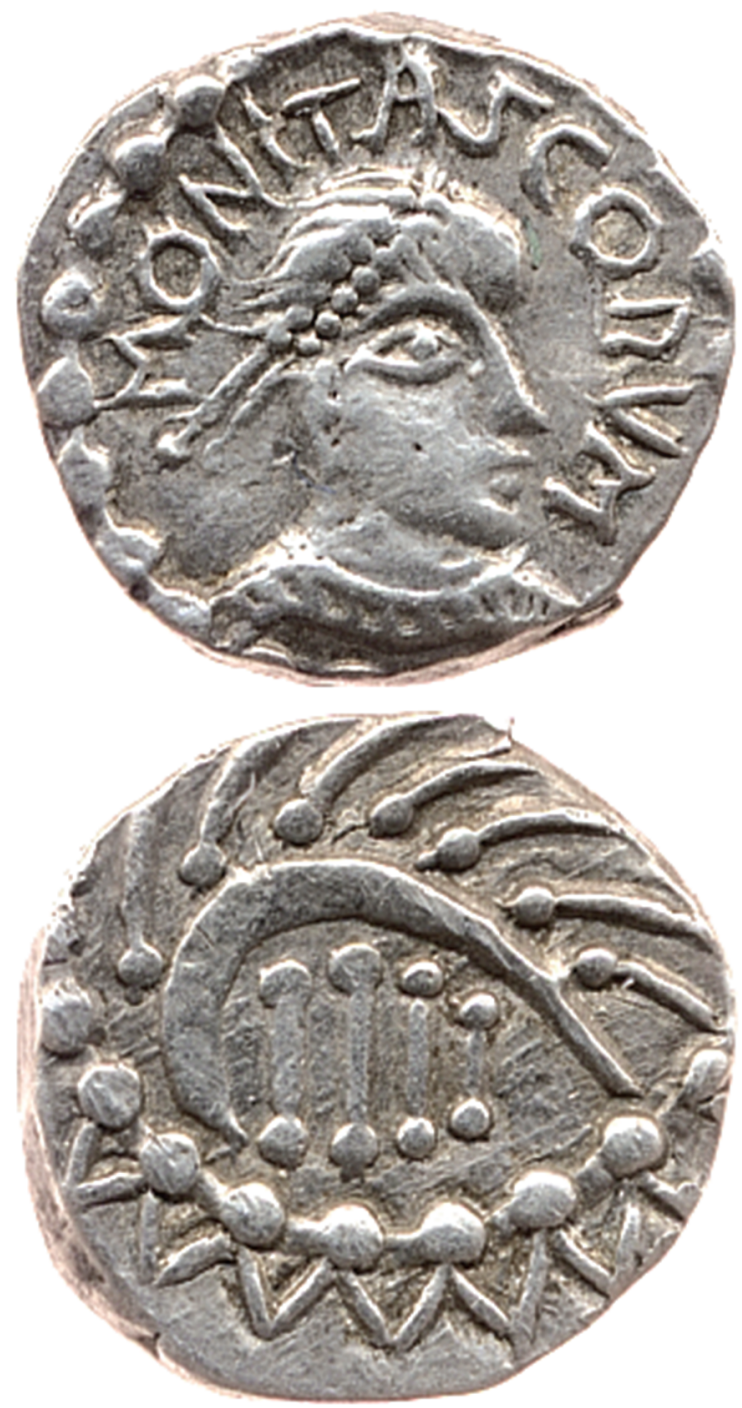

FIGURE 12.6A MONITASCORVM type, Type 9 variant.

SOURCE: FitZWILLIAM MUSEUM, CAMBRIDGE (MEC 8, NO. 437; CM.1837$2007)$.

interactions with the objects themselves; this accounts for the degeneration in both image and script, although it is important to note that both were retained. The very conservative Series $C$ and $R$, which descend via coins of Series A from pale gold issues of the 65 os, can also be said to be the most bureaucratic. ${ }^{84}$

84 Gannon, Iconography, pp. 42-45 and fig. 2.28. 

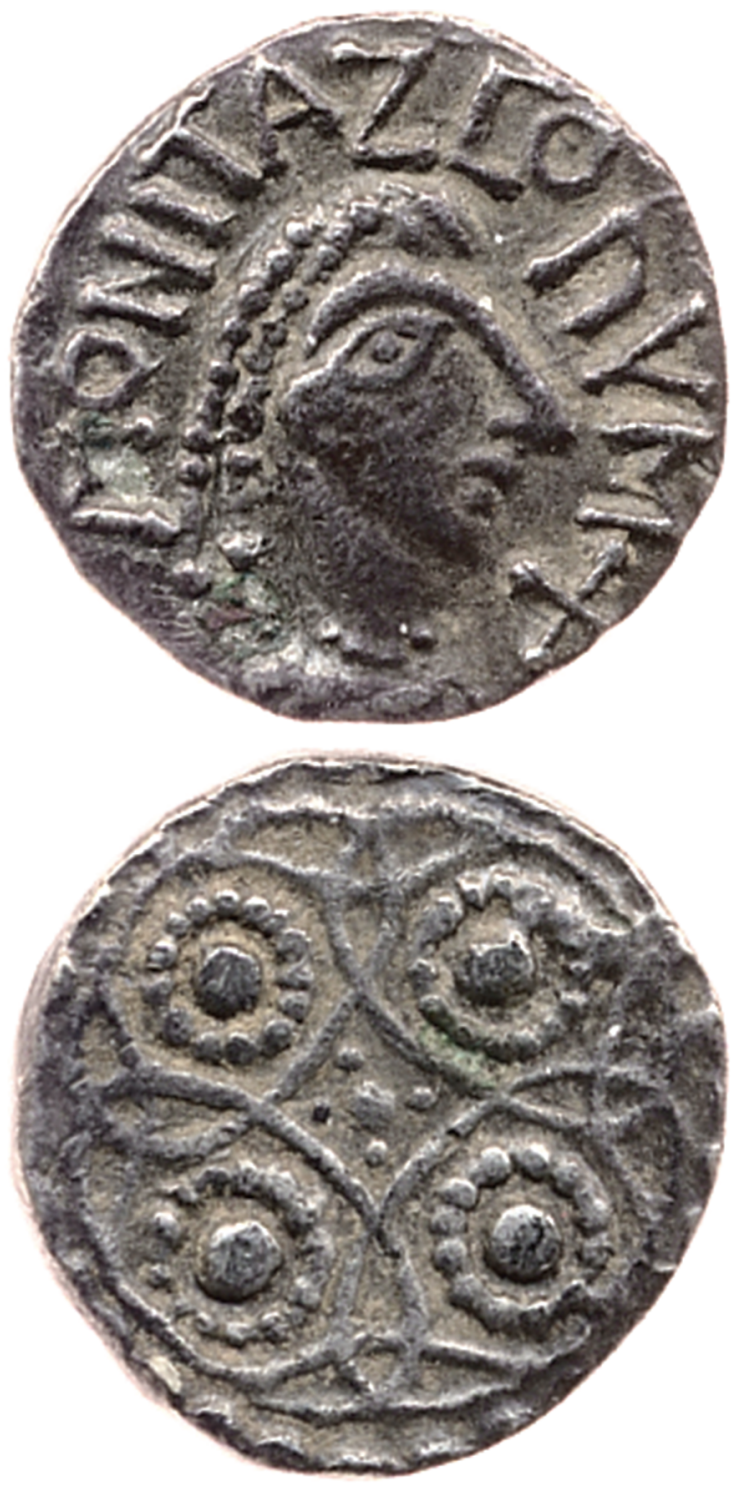

FIGURE 12.6B MONITASCORVM type, Type 14 variant.

SOURCE: FitZWILliAM MUSEUM, CAMBRIDGE (MEC 8, NO. 439; CM.1838$2007)$.

Among other sceattas, it is quite a different story. In some cases, the imagery itself is so dense that, even if not accompanied by an inscription, it can be postulated to be emblematic for entire passages of text, as in the case for coins featuring birds in vines, which allude to the lines "I am the true vine" in the Gospel 
of St John (15:1-8) (Figure 12.7). ${ }^{85}$ This is a very encouraging passage, promising food, refuge, and life: a visualization of Paradise of universal appeal that everybody would have been able to connect to and appreciate in its basic simplicity.

If in the silver series both artistic verve and iconographic choices demonstrate a new sense of confidence on the part of the coin designers, the moneyers and the authority behind the coinage (whoever that was) appear to have been established enough to sponsor original designs and explore new ideas in some cases even to the extent of doing away with traditional busts and so blurring distinctions between obverse and reverse. While it is clear that all types of sceattas were used for transactions, the sophistication of the iconographies and their execution appear remarkable enough to lead to speculations that religious-themed coins had supplementary functions in addition to purely commercial ones. ${ }^{86}$ It should be noted that sceattas, rather than showing a great number of different types (as numismatists tend to classify them according to diversity), actually have a few main themes which are expressed according to regional artistic variations. As examples, one might consider the different representations of lions, which we can define as "local".87

Although undoubtedly sceattas are the most engaging of all Anglo-Saxon coins, and certainly the ones which, as an art historian, I have most enjoyed writing about, these beautiful, creative coins are as ephemeral as they are unique. Their complex imagery was all but swept away by the monetary reforms of the mid-8th century which saw the adoption of explicitly royal coinages, mainly adhering to the well-established pattern of bust/cross/inscription. This combination would prove to be the fundamental blueprint for medieval coins for centuries to come and facilitated plenty of opportunities for interesting variations and experimentation.

\section{Offa's Reform}

The most justly celebrated of the reformed coinages of the end of the 8th century is that of King Offa of Mercia, which has been painstakingly collected, studied, and written about. ${ }^{88}$ It still lacks a systematic art historical survey - and

\footnotetext{
85 Hawkes, "The plant-life of early Anglo-Saxon art", pp. 275-82; Gannon, Iconography, pp. 117-20. Coins with birds in vine-scrolls find counterparts in much metalwork and sculpture of the time, most famously on the Ruthwell and Bewcastle crosses. Ó Carragáin, Ritual and the Rood, pp. 285-87.

86 Gannon, "Firmly I believe and truly".

87 The lion theme is discussed in detail in Gannon, Iconography, pp. 125-35.

88 Chick, Offa; Naismith, Money and Power.
} 

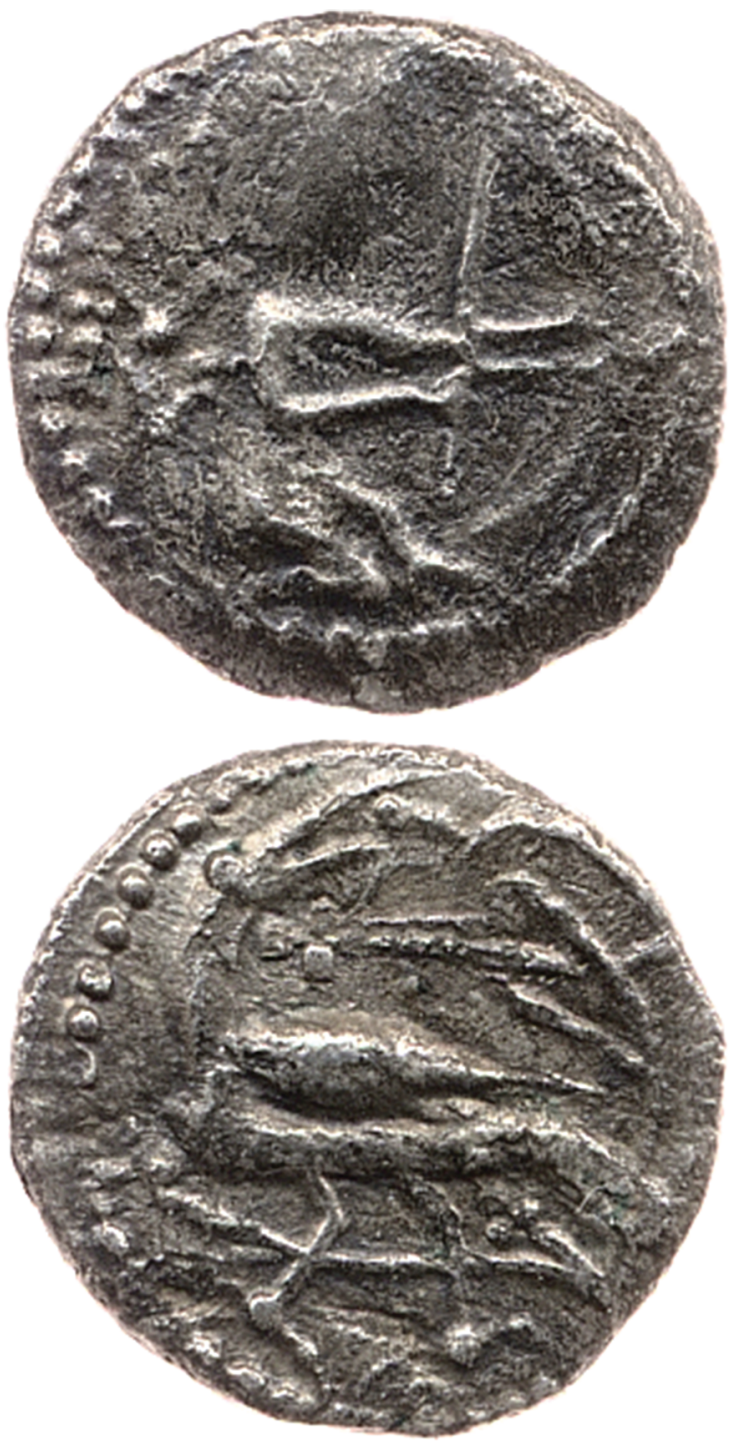

FIGURE 12.7 Archer Group, Type 94. SOURCE: FitZWILLIAM MUSEUM, CAMBRIDGE (MEC 8, NO. 442; CM.1840$2007)$.

indeed, to do justice to the remarkable variety and elegance of the many types that made up Offa's coinage would call for a major publication rather than a general survey. Some of its most striking busts, however, have already attracted comments. ${ }^{89}$ The fact that the busts could be conceived so as to portray King

89 Gannon, Iconography, pp. 31-33 and 59-61; Naismith, Money and Power, pp. 54-64. 
Offa while hinting at the personas and qualities of King David or the Emperor Constantine - and even going as far as showing Offa bare-chested as "heroic nude" - as the embodiment of "those virtues that made a man seem like a hero to his contemporaries" ${ }^{\prime 90}$ force us to further our understanding of how coinage iconography was made to work at the time.

In addition to being explicitly royal, the imagery could be manipulated to convey subtle messages of propaganda. This is quite a self-assured leap, perhaps consciously coming full circle with the way Roman coinage was used for political means, including producing coins with the representation of the royal spouse.${ }^{91}$ Queen Cynethryth's coins are equally extraordinary: judging by the numbers of known specimens and their variety they must have been quite substantial productions, with a different distribution pattern from Offa's, but a function not yet fully understood. ${ }^{92}$ All of the ten known types produced in Cynethryth's name, including the three which (re)use busts of Offa, display her name and title on the reverse around a beaded circle containing the ornamental uncial M (for Merciorum). The name of the only moneyer to work for her, Eoba, is on the obverse, in front of the image. ${ }^{93}$ One of the issues facing coin designers was the length of names. Cynethryth's, of course, was too long to fit in front of her bust, but here too we can imagine that the inscription gives voice to her command to the moneyer, which here particularly serves to stress her authority. An interesting comparison is with coins of Offa by the moneyer Ibba, where the two name inscriptions are interchangeable between obverse and reverse. In this case, either Ibba's or Offa's four characters could be made to fit neatly among the foliate extensions sprouting at the four corners of the central lozenge with inner cross that features on the reverse.

Offa's coinage is distinctive among contemporary coin issues, both in England and on the Continent, on account of the variety and inventiveness of the iconography used. It is also remarkable, especially as it was striving towards standardization. The majority of the designs and dispositions of lettering and inscriptions are to be read as variations and expansions on the motif of the cross. ${ }^{94}$ In the wake of the various theological issues and controversies which had rocked Byzantium and Rome and which even came to be mirrored in the

\footnotetext{
90 Hallett, The Roman Nude, p. 219; Gannon, Iconography, p. 61; Chick, Offa, pp. 57-6o (Light coinage of London), types 8-10.

91 Naismith, Money and Power, pp. 62-64.

92 Chick, Offa, pp. 123-28, types 138-48.

93 Chick, Offa, pp. 83-86, types 51-53 with moneyer's name on obverse and types 54-57 with moneyer's name on reverse.

94 Gannon, Iconography, pp. 168-71.
} 
sceattas, the cross increased in importance both devotionally and visually. ${ }^{95}$ Building on a devotional tradition of attentive deciphering of patterns to discover hidden crosses, Offa's moneyers managed to balance the intellectual inventiveness of the artistic tradition with the more sober needs of monetary reform and conformity, with brilliant results. ${ }^{96}$ Artistically, Offa's time can be defined as Mercia's golden age, as amply testified to by what remains of its intellectual and material culture, with impressive achievement in metalwork, manuscripts, and sculpture. All showed a creative blend of old traditions with new interpretations of classicism as well as novel, exotic input. ${ }^{97}$ It is therefore no surprise that Offa's coinage, too, should be so full of interest and so accomplished artistically as to stand comparison with even that of Charlemagne and his powerful kingdom.

\section{Conclusion}

Visually, then, Anglo-Saxon coinage may be said to have moved little over the span of 200 years: coins still featured a bust on the obverse, a cross on the reverse, and inscriptions. However, as this chapter has argued, the numismatic tradition was a rich cultural tapestry enhanced by a variety of artistic and cultural contributions which demonstrate what depth of meaning can underpin iconography.

We have seen how the gold coinage moved swiftly and decidedly away from slavish imitations of Merovingian prototypes to explore more ambitious and complex Roman examples, and how, additionally, influential input came from first-hand contact with ancient British coins, which contributed to a number of features. The early Anglo-Saxon coins, particularly those produced during the pale-gold and pre-primary phases $(c .650-680)$ bear witness to freedom and ambition, guided by a desire for designs to have a local cultural resonance, hence the richness of fine details and texture, particularly in the busts. The vast production of silver coinage, the sceattas $\left(68 \mathrm{os}-75^{\circ}\right)$, especially at the turn of the 8th century, testifies to the busy commercial world of the North Sea. High numbers, the need for quick production, and international use meant that coin iconography had to be simplified drastically, resulting in some rather pedestrian productions, such as the Porcupines, which reduced busts and

95 Gannon, "Firmly I believe and truly"; Naismith, Money and Power, pp. 69-71.

96 Pirotte, "Hidden order, order revealed".

97 See essays in Brown and Farr, Mercia. 
inscriptions to a few emblematic lines combined with simple reverses with standards. Alongside these, almost as a reaction, were the rich and varied coins displaying quite remarkable artistic designs, often of outstanding merit and always full of interest for the breadth of discernible influences and models and for their intellectual content. If the reforms of the mid-8th century, striving towards standardization and a stronger and explicit royal grip, swept away the sceattas, the new coins certainly built on their inheritance of inventiveness and variety, albeit within strict rules. The coinage of Offa of Mercia demonstrates a lively artistic interest and engagement with the possibilities offered by the combination of bust/inscription/cross, which would lay the foundations of medieval coinage for centuries to come.

Hence, the best art historical definition to encompass the whole of the early Anglo-Saxon coinage highlights creativity within tradition and an acute awareness of the connectivity of the times, as well as the tumultuous changes, crises, aspirations, and triumphs that history records.

\section{Bibliography}

Abdy, R., and Williams, G., "A catalogue of hoards and single finds from the British Isles, c.AD 410-675", in Cook and Williams, Coinage and History in the North Sea World, 2006, 11-73.

Adams, N., "Rethinking the Sutton Hoo shoulder clasps and armour", in C. Entwistle and N. Adams (eds.), Intelligible Beauty: Recent Research on Byzantine Jewellery, London, 2010, 83-112.

Archibald M., "Numismatics and the chronological model", in J. Hines and A. Bayliss (eds.), Anglo-Saxon Graves and Grave Goods of the 6th and 7 th Centuries AD: A Chronological Framework, London, 2013, 493-515.

Archibald, M., "The Wilton Cross coin pendant: numismatic aspects and implications", in A. Reynolds and L. Webster (eds.), Early Medieval Art and Archaeology in the Northern World, Leiden, 2013, 51-71.

Archibald, M.M., and Blunt, C.E., British Museum Anglo-Saxon Coins 5: Athelstan to the Reform of Edgar 924-c.973 (Sylloge of Coins of the British Isles, 34), London, 1986.

Attenborough F.L., The Laws of the Earliest English Kings, Cambridge, 1922.

Boulton, M., Hawkes, J., and Herman, M. (eds.), The Art, Literature and Material Culture of the Medieval World: Transition, Transformation and Taxonomy, Dublin, 2015.

Brown, M., and Farr, C. (eds.), Mercia: An Anglo-Saxon Kingdom in Europe, London, 2001.

Campbell, J., "The first Christian kings", in J. Campbell (ed.), The Anglo-Saxons, Oxford, 1982, 45-69. 
Carver, M.O.H., Sutton Hoo: A Seventh-Century Princely Burial Ground and Its Context (Reports of the Research Committee of the Society of Antiquaries of London, 69), London, 2005 .

Chick, D., Blackburn, M., and Naismith, R. (eds.), The Coinages of Offa and His Contemporaries, London, 2010.

Coates-Stephens, R., "Epigraphy as spolia: the reuse of inscriptions in early medieval buildings", Papers of the British School at Rome 70 (2002), 274-96.

Cook, B., and Williams, G. (eds.), Coinage and History in the North Sea World (c.50o1250), Leiden, 2006.

Cottam, E., de Jersey, P., Rudd, C., and Sills, J., Ancient British Coins, Aylsham, 2010.

Coz, Y., Rome en Angleterre: l'image de la Rome antique dans l'Angleterre Anglo-Saxonne, du VIIe siècle à 1066, Paris, 2011.

Eaton, T., Plundering the Past: Roman Stonework in Medieval Britain, Stroud, 2000.

Esmonde Cleary, A.S., The Ending of Roman Britain, London, 1989.

Farley, J., and Fraser Hunter, H. (eds.), Celts: Art and Identity, London, 2015.

Gannon, A., British Museum Anglo-Saxon Coins I: Early Anglo-Saxon Coins and Continental Silver Coins of the North Sea, c.6oo-76o (Sylloge of Coins of the British Isles, 63), London, 2013.

Gannon, A., "Coins, images and tales from the Holy Land: questions of theology and orthodoxy", in T. Abramson (ed.), New Perspectives (Studies in Early Medieval Coinage, 2), Woodbridge, 2011, 88-103.

Gannon, A., "Early Anglo-Saxon coins: iconography and the visual imagination", in J.D. Niles, S.S. Klein, and J. Wilcox (eds.), Anglo-Saxon England and the Visual Imagination: Proceedings of the ISAS Conference, Madison 2011, Tempe, 2016.

Gannon, A., "Firmly I believe and truly: religious iconography on early Anglo-Saxon sceattas", in N.M. Burström and G.T. Ingvardson (eds.), Divina Moneta: Coins in Religion and Ritual, Abingdon, 2018, 125-41.

Gannon, A., The Iconography of Early Anglo-Saxon Coinage, Oxford, 2003.

Gannon, A., "The iconography of series M, variant and the Agnus Dei", in M. Allen, R. Naismith, and E. Screen (eds.), Early Medieval Monetary History: Studies in Memory of Mark Blackburn, Farnham, 2014, 157-71.

Gannon, A., "Imitation is the sincerest form of flattery", in Cook and Williams, Coinage and History in the North Sea World, 2006, 193-208.

Gannon, A., "Money, power and women: an inquiry into early Anglo-Saxon coinage", in S. Solway (ed.), Medieval Coins and Seals: Constructing Identity, Signifying Power, Leiden, 2015, 211-28.

Gannon, A., "Insular numismatics: the relationship between ancient British and early Anglo-Saxon coins", in T. Martin and W. Morrison (eds.), Barbaric Splendour: The Use of Image in Europe before and after Rome, forthcoming. 
Gannon, A., "Three coins in a fountain”, in É.Ó Carragáin and C.L. Neuman de Vegvar (eds.) Roma Felix: Formation and Reflections of Medieval Rome, Aldershot, 2007, 287-306.

Hallet, C.H. The Roman Nude: Heroic Portrait Statuary 200 B.C.-A.D. 300 , Oxford, 2005. Hauck, K., "Gott als Arzt: eine exemplarische Skizze mit Text- und Bildzeugnissen aus drei ver-schiedenden Religionen zu Phänomenen und Gebärden der Heilung (Zur Ikonologie der Gold-brakteaten XIV)", in C. Meier and U. Ruberg (eds), Text und Bild: Aspekte des Zusammenwirkens zweier Künste in Mittelalter und früher Neuzeit, Wiesbaden, 1980, 19-62.

Hawkes, J., "The plant-life of early Anglo-Saxon art", in C. Biggam (ed.), From Earth to Art: Early Medieval Plant Studies, Amsterdam, 2003, 263-86.

Henderson, G., Vision and Image in Early Christian England, Cambridge, 1999.

Hobbs, R. British Iron Age Coins in the British Museum, London, 1996.

Howe, N., "Anglo-Saxon England and the postcolonial void", in A.J. Kabir and D. Williams (eds.), Postcolonial Approaches to the European Middle Ages: Translating Cultures, Cambridge, 2005, 25-47.

Howe, N., Writing the Map of Anglo-Saxon England: Essays in Cultural Geography, New Haven, 2008.

Karkov, C.E., The Art of Anglo-Saxon England, Woodbridge, 2011.

Karkov, C.E., The Ruler Portraits of Anglo-Saxon England, Woodbridge, 2004.

Kuhn, S.L., "Signaling theory and technologies of communication in the Paleolithic", Biological Theory 9:1 (2014), 42-5o.

Mattingly, H., Sydenham, E.A., et al. (eds.), The Roman Imperial Coinage, 10 vols., London, 1923-1994.

Meaney, A., Anglo-Saxon Amulets and Curing Stones (BAR British Series, 96), Oxford, 1981 .

Metcalf, D.M., Thrymsas and Sceattas in the Ashmolean Museum, Oxford, London, 1993-1994.

Moss, R. (ed.), Making and Meaning in Insular Art: Proceedings of the Fifth International Conference on Insular Art (Trinity College Dublin 25-28 August 2005), Dublin, 2007.

Naismith, R., Money and Power in Anglo-Saxon England: The Southern English Kingdoms, 757-865, Cambridge, 2012.

Naismith, R., "Money of the saints: church and coinage in early Anglo-Saxon England", in T. Abramson (ed.), Sifting the Evidence (Studies in Early Medieval Coinage, 3), London, 2014, 6o-113.

Neuman de Vegvar, C., "The travelling twins: Romulus and Remus in Anglo-Saxon England", in J. Hawkes and S. Mills (eds.), Northumbria's Golden Age, Stroud, 1999, 256-67.

Ó Carragáin, É., Ritual and the Rood, London, 2005. 
Ó Carragáin, É., and Thacker, A., "Wilfrid in Rome", in N.J. Higham (ed.), Wilfrid: Abbot, Bishop, Saint: Papers from the 13ooth Anniversary Conferences, Donington, 2013, 212-3o.

Pirotte, E., "Hidden order, order revealed: new light on carpet pages", in M. Redknap, N. Edwards, S. Youngs, A. Lane, and J. Knight (eds.), Pattern and Purpose in Insular Art: Proceedings of the Fourth International Conference on Insular Art Held at the National Museum and Gallery, Cardiff 3-6 September 1998, Oxford, 2001, 203-7.

Plunkett, S., "The Mercian perspective", in S.M. Foster (ed.), The St Andrews Sarcophagus, Dublin, 1998, 202-26.

Stahl, M., "The nature of the Sutton Hoo coin parcel", in C.B. Kendall and P.S. Wells (eds.), Voyage to the Other World: The Legacy of Sutton Hoo, Minneapolis, 1992, 3-14.

Webster, L., Anglo-Saxon Art: A New History, London, 2012.

Webster, L., The Franks Casket, London, 2012.

Webster, L., "The iconographic programme of the Franks casket", in J. Hawkes and S. Mills (eds.), Northumbria's Golden Age, Stroud, 1999, 227-46.

Webster, L., and Brown, M. (eds.), The Transformation of the Roman World, AD 400-90o, London, 1997.

White, R.H., Roman and Celtic Objects from Anglo-Saxon Graves: A Catalogue and an Interpretation of Their Use (British Archaeological Reports British Series, 191), Oxford, 1998.

Williams, G., "The circulation and function of coinage in conversion-period England, c.AD 580-675", in Cook and Williams, Coinage and History in the North Sea World, 2006, 145-92.

Williams, G., "Coin-brooches of Edward the Confessor and William I", British Numismatic Journal 71 (2001), 6o-70.

Williams, J., "Coin inscriptions and the origins of writing in pre-Roman Britain", British Numismatic Journal 71 (2001), 1-17.

Wood, I.N., "Ripon, Francia and the Franks casket in the early Middle Ages", Northern History 26 (1990), 1-19. 